Supplement of Atmos. Chem. Phys., 16, 5497-5512, 2016

http://www.atmos-chem-phys.net/16/5497/2016/

doi:10.5194/acp-16-5497-2016-supplement

(C) Author(s) 2016. CC Attribution 3.0 License.

(c) (i)

Supplement of

\title{
Chemical and physical characterization of traffic particles in four different highway environments in the Helsinki metropolitan area
}

Joonas Enroth et al.

Correspondence to: Liisa Pirjola (liisa.pirjola@metropolia.fi, liisa.pirjola@ helsinki.fi)

The copyright of individual parts of the supplement might differ from the CC-BY 3.0 licence. 
Table S1. Aerosol instrumentation used in the mobile laboratory Sniffer.

\begin{tabular}{|l|l|l|}
\hline Instrument & Measured parameter & Time resolution \\
\hline $\begin{array}{l}\text { CPC (Condensation } \\
\text { Particle Counter, TSI) }\end{array}$ & $\begin{array}{l}\text { particle number } \\
\text { concentrations } \\
\text { (diameter }>2.5 \mathrm{~nm})\end{array}$ & $1 \mathrm{~s}$ \\
\hline $\begin{array}{l}\text { ELPI (Electrical Low } \\
\text { Pressure Impactor, } \\
\text { Dekati) }\end{array}$ & $\begin{array}{l}\text { size distribution, aerodynamic } \\
\text { diameter } 7 \mathrm{~nm}-10 \mu \mathrm{m}\end{array}$ & $1 \mathrm{~s}$ \\
\hline $\begin{array}{l}\text { ELPI + Thermodenuder } \\
\text { (TD) }\end{array}$ & $\begin{array}{l}\text { particle volatility in the } \\
\text { size range } 7 \mathrm{~nm}-10 \mu \mathrm{m}, \\
\text { heated to } 265{ }^{\circ} \mathrm{C}\end{array}$ & $1 \mathrm{~s}$ \\
\hline $\begin{array}{l}\text { EEPS (Engine Exhaust } \\
\text { Particle Sizer, model } \\
3090, \text { TSI) }\end{array}$ & $\begin{array}{l}\text { size distribution, mobility } \\
\text { particle size } 5.6-560 \mathrm{~nm}\end{array}$ & $1 \mathrm{~s}$ \\
\hline $\begin{array}{l}\text { Aethalometer ( Magee } \\
\text { Scientific Model AE 33) }\end{array}$ & $\begin{array}{l}\text { black carbon in PM } 1 \text { size } \\
\text { fraction }\end{array}$ & $10 \mathrm{~s}$ \\
\hline $\begin{array}{l}\text { DustTrak (TSI) } \\
\text { Sp-AMS (Soot Particle }\end{array}$ & PMar.5 & $1 \mathrm{~s}$ \\
\hline particle chemistry & $5 \mathrm{~s}$ \\
\hline
\end{tabular}

Table S2. Distances at which the traffic-related pollutant concentrations (background concentrations were first subtracted) were halved from the concentrations at the highway.

$\begin{array}{lcccccc} & \begin{array}{c}\text { Ntot } \\ (\mathrm{m})\end{array} & \begin{array}{c}\mathrm{PM}_{1} \\ (\mathrm{~m})\end{array} & \begin{array}{c}\mathrm{BC} \\ (\mathrm{m})\end{array} & \begin{array}{c}\text { Org } \\ (\mathrm{m})\end{array} & \begin{array}{c}\mathrm{NO} \\ (\mathrm{m})\end{array} & \begin{array}{c}\mathrm{NO}_{2} \\ (\mathrm{~m})\end{array} \\ \text { Herttoniemi } & 39 & 26 & 40 & 24 & 26 & 56 \\ \text { Malmi } & 83 & 75 & 50 & 34 & 38 & 374 \\ \text { Itä-Pakila } & 8 & 3 & 9 & <6 & 13 & 12 \\ \text { Pitkäjärvi } & 40 & 28 & 31 & 38 & 25 & 90\end{array}$


Table S3. The ratio of NO to $\mathrm{NO}_{2}$ as a function of distance from the highway.

\begin{tabular}{lrrrr}
$\begin{array}{l}\text { Distance } \\
(\mathrm{m})\end{array}$ & Herttoniemi & Malmi & \multicolumn{1}{c}{$\begin{array}{l}\text { Itä- } \\
\text { Pakila }\end{array}$} \\
Road & 1.80 & 2.77 & 1.54 & Pitkäjärvi \\
Roadside & 1.14 & 1.40 & 1.29 & 2.54 \\
25 & 1.07 & 1.30 & 1.10 & 1.69 \\
50 & 1.06 & 0.91 & 0.50 & 1.50 \\
75 & 1.12 & 0.82 & 0.44 & 0.89 \\
100 & 1.20 & 0.68 & 0.34 & 0.78 \\
125 & 0.83 & 0.63 & 0.27 & 0.70 \\
150 & & 0.57 & 0.21 & 0.61 \\
175 & & 0.79 & 0.20 & 0.54 \\
200 & & 0.27 & 0.14 & 0.49 \\
225 & & & 0.15 & 0.46 \\
250 & & & 0.15 & 0.46 \\
Background & 0.04 & 0.15 & 0.19 & 0.22
\end{tabular}

Table S3. Average particle diameter $(\mathrm{nm})$ of the size distribution as a function of distance from the roadside at different locations. Measurements were carried out by the EEPS.

$\begin{array}{lccccc}\text { Dave }(\mathrm{nm}) & \text { Highway } & \begin{array}{c}\text { Roadside } \\ 0 \mathrm{~m}\end{array} & \begin{array}{c}50 \\ \mathrm{~m}\end{array} & \begin{array}{c}100 \\ \mathrm{~m}\end{array} & \text { Background } \\ \text { Herttoniemi } & 25.4 & 26.2 & 29.0 & 25.8 & 22.0 \\ \text { Malmi } & 26.9 & 23.4 & 24.2 & 27.5 & 29.8 \\ \text { Itä-Pakila } & 27.0 & 29.5 & 30.5 & 33.0 & 35.6 \\ \text { Pitkäjärvi } & 18.8 & 21.3 & 22.5 & 22.0 & 24.2\end{array}$




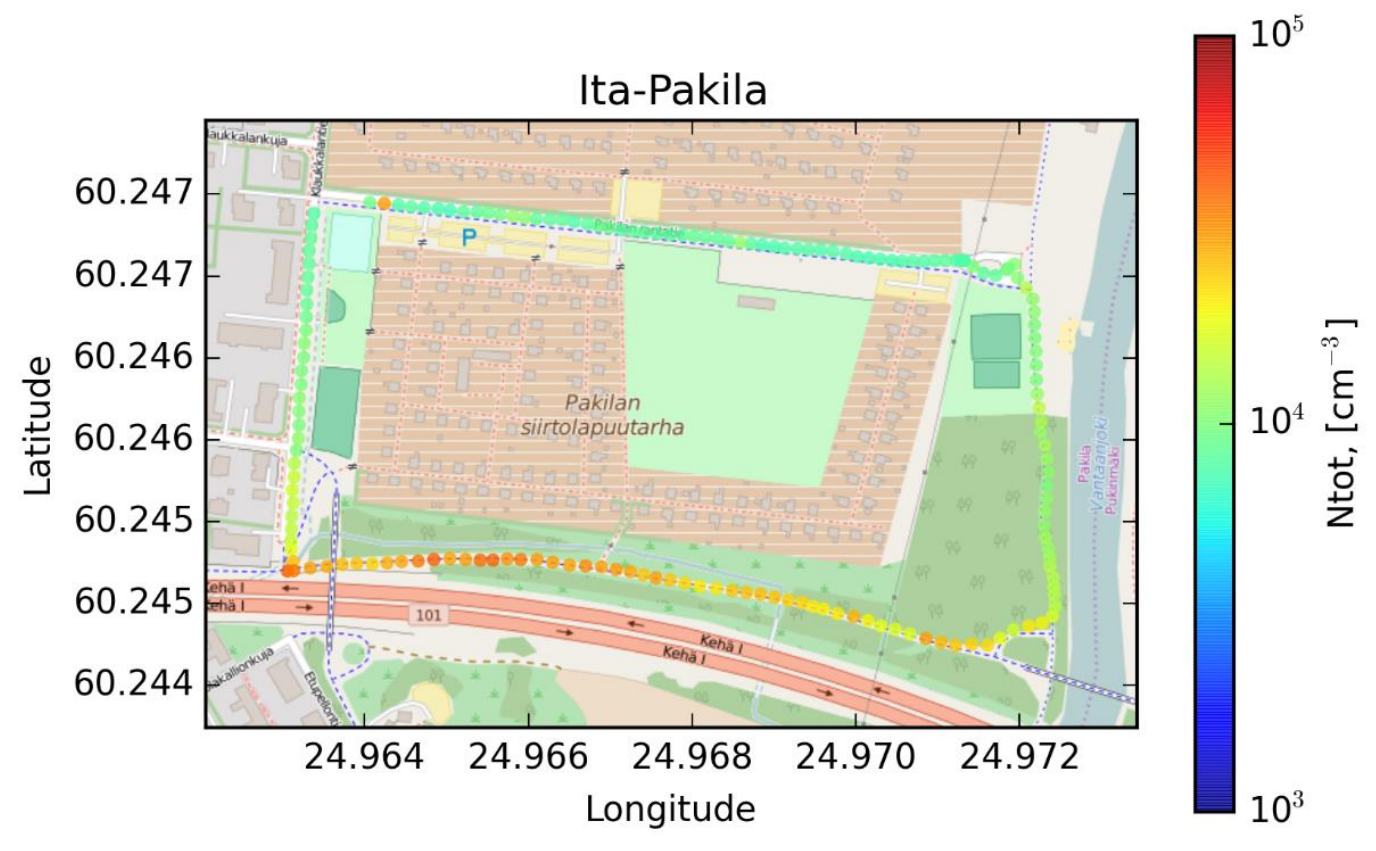

Figure S1. Total PN concentration averaged over all measurement loops at Itä-Pakila.

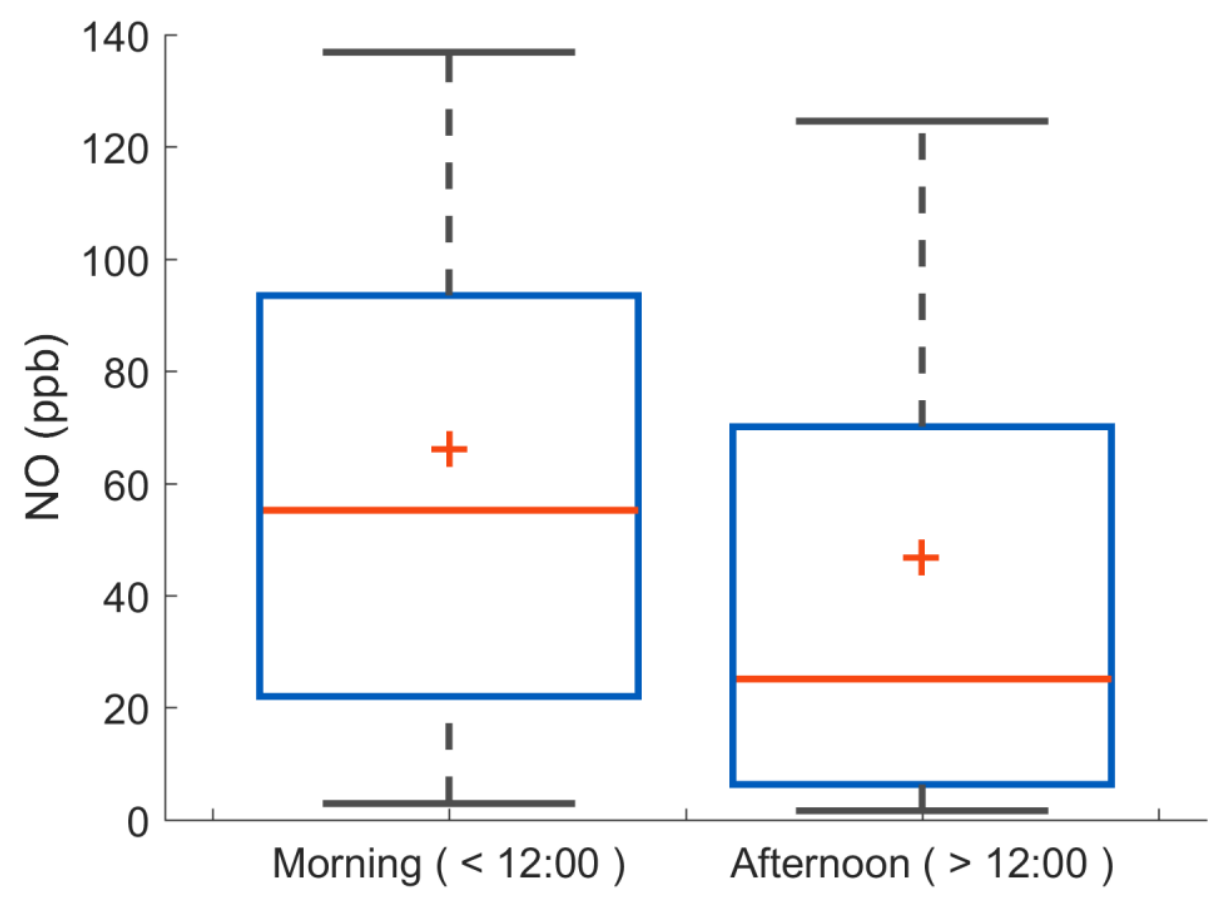

Figure S2. Average NO concentrations for the entire dataset separated based on the division of morning and evening rush hour occasions. Red line refers to median, plus sign to mean, blue box to 25 and 75 percentiles, and black whiskers to 10 and 90 percentiles. 


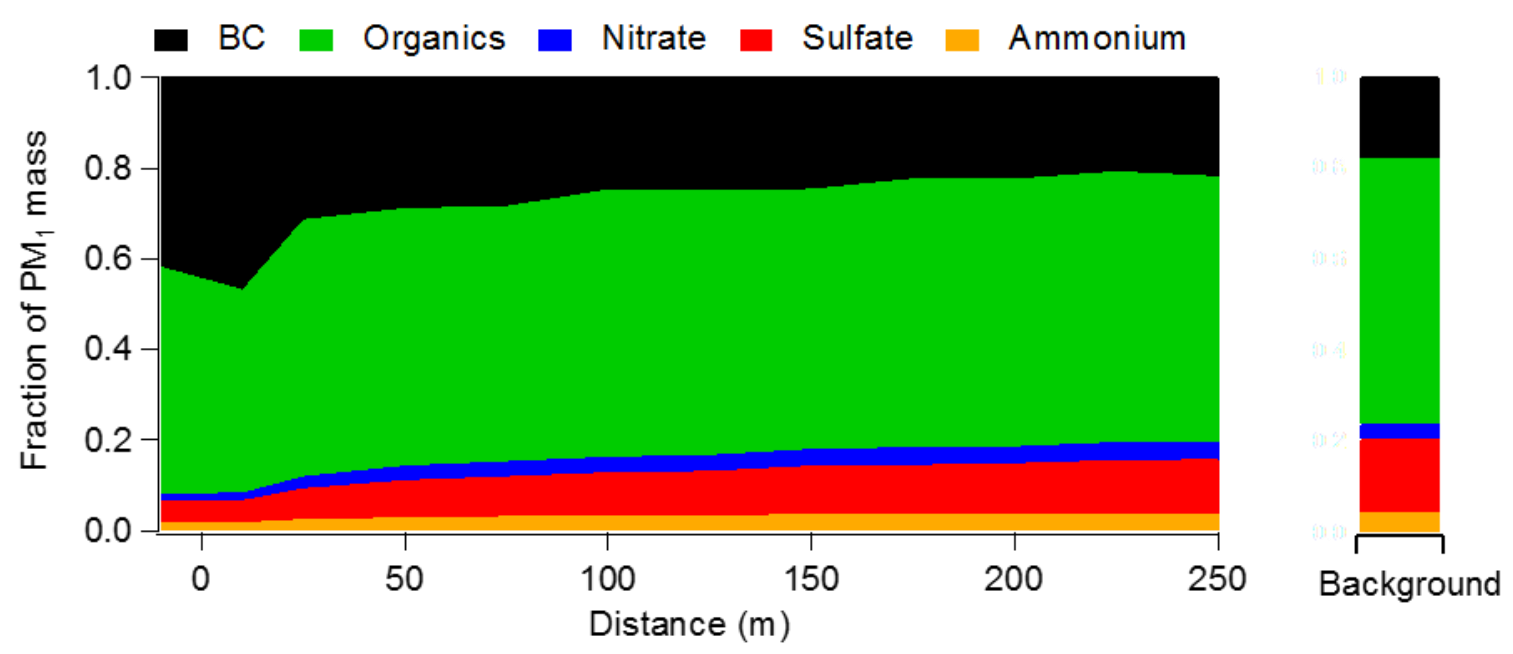

Figure $\mathrm{S} 3 . \mathrm{PM}_{1}$ mass fractions of $\mathrm{BC}$, organics, nitrate, sulfate and ammonium measured at different distances from the road at Pitkäjärvi. Background concentrations are not subtracted.

a)

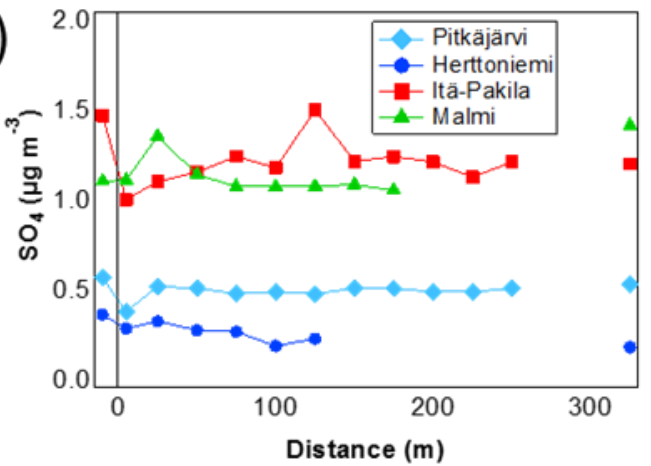

c)

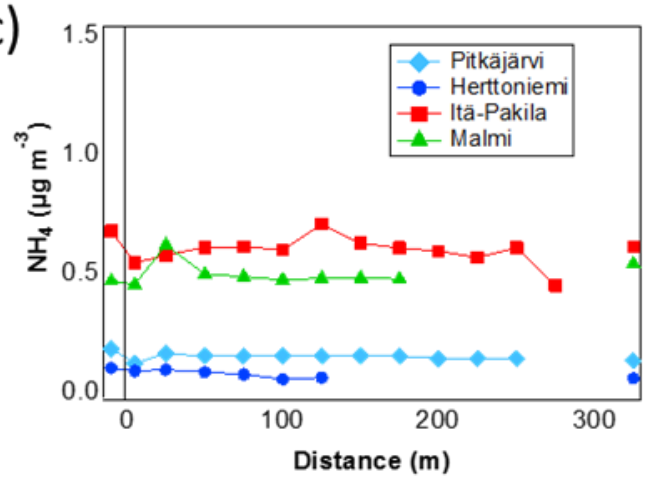

b)

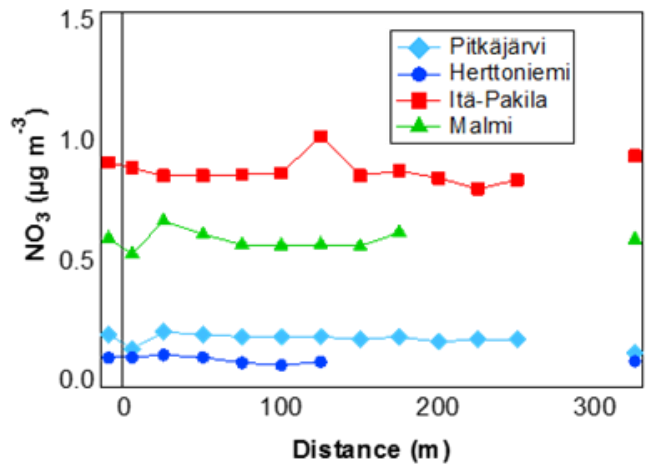

d)

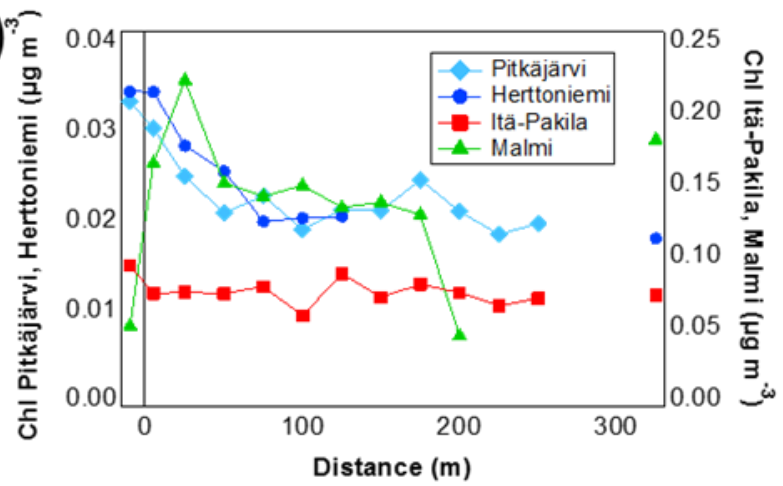

Figure S4. Concentration gradients for sulfate (a), nitrate (b), ammonium (c), and chloride (d) from each of the four locations. Zero distance refers to the roadside, negative value driving on the highway, and rightmost value to background site ( $\geq 500 \mathrm{~m}$ from the road). Background concentration were not subtracted from the measured concentrations. 

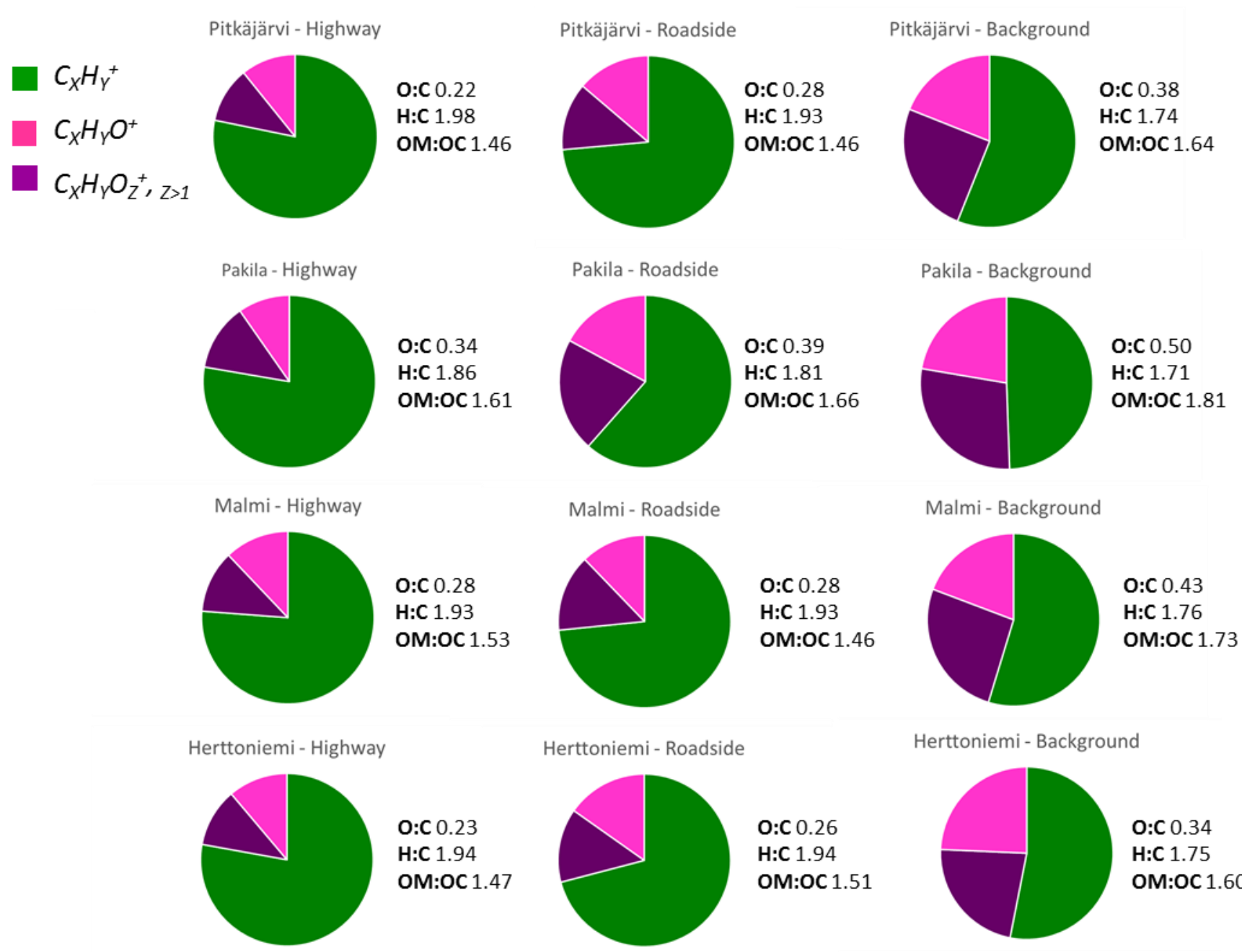

O:C 0.26

H:C 1.94

OM:OC 1.51

Herttoniemi - Background

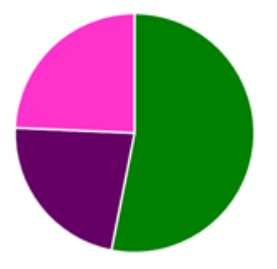

O:C 0.34

H:C 1.75

OM:OC 1.60

Figure S5. The composition of organic fragments at Pitkäjärvi, Itä-Pakila, Malmi and Herttoniemi for highway, roadside and background locations. $\mathrm{C}_{X} \mathrm{H}_{Y}{ }^{+}$refers to hydrocarbon fragments, $\mathrm{C}_{X} \mathrm{H}_{Y} \mathrm{O}^{+}$ to organic fragments with one oxygen atom and $\mathrm{C}_{X} \mathrm{H}_{Y} \mathrm{OZ}_{Z}^{+}, \mathrm{Z}_{>1}$ to organic fragments with more than one oxygen atom. 

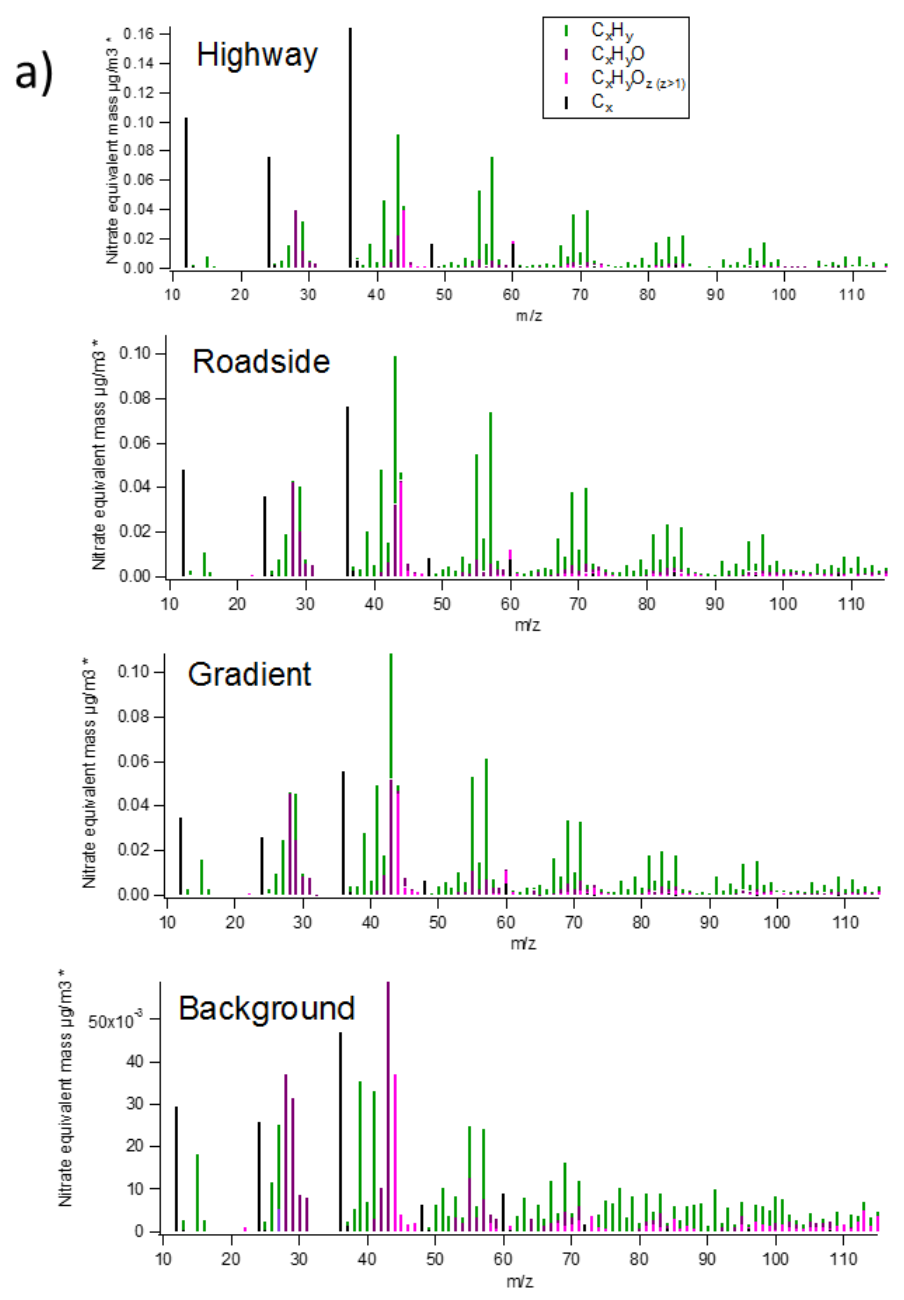

b)

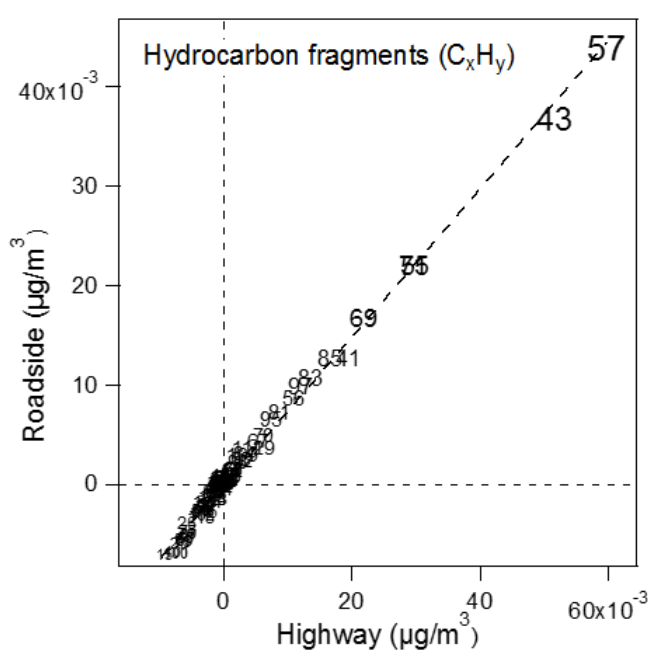

c)

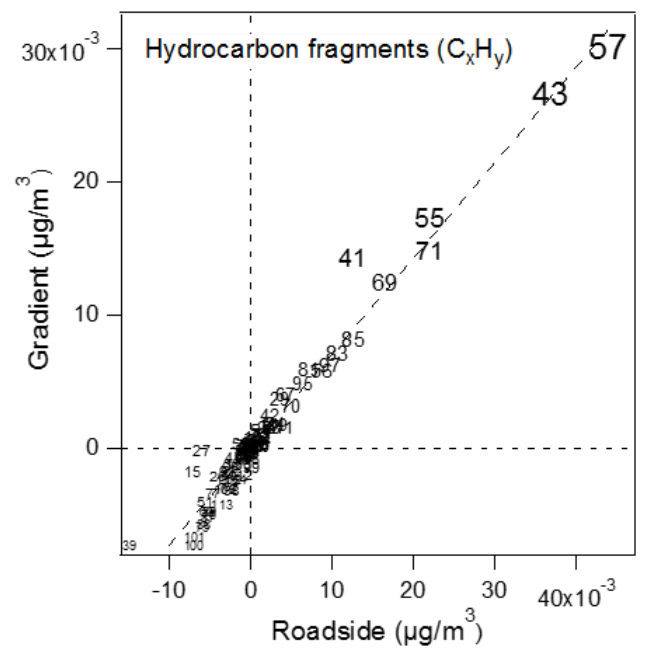

Figure S6 Mass spectra for organics and $r B C$ measured at highway, roadside, gradient, and background at Pitkäjärvi (a), the scatter plots for hydrocarbon fragments for roadside and highway (b), and gradient and roadside (c). Gradient refers to the average concentration over all distances, $C_{X} H_{Y}$ refers to hydrocarbon fragments, $\mathrm{C}_{X} \mathrm{H}_{Y} \mathrm{O}$ to organic fragments with one oxygen atom, $\mathrm{C}_{X} \mathrm{H}_{Y} \mathrm{O}_{Z, Z>1}$ to organic fragments with more than one oxygen atom and $C_{x}$ to carbon fragments. Note different scales of the y-axes. Hydrocarbon fragments measured at background are subtracted in (b) and (c). Marker size is scaled based on the concentration in (b) and (c). 


\section{Roadside}

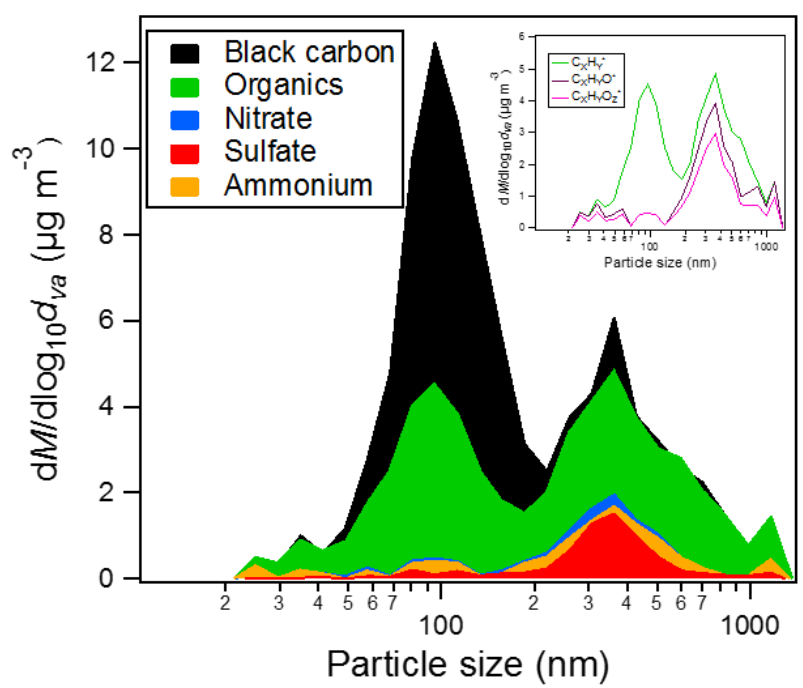

Background

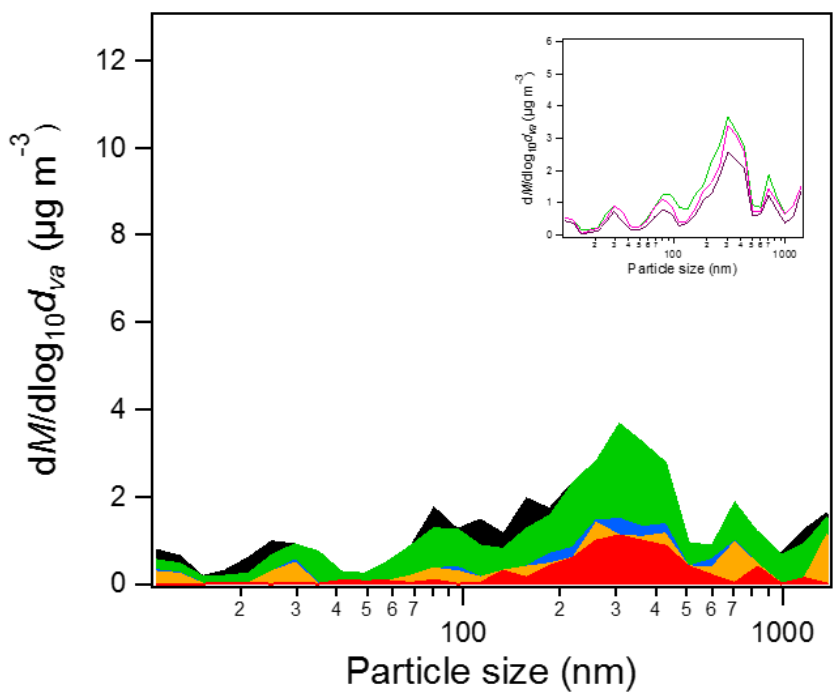

Figure S7- Mass size distribution measured at the roadside and background at Pitkäjärvi. The composition of organics is presented in insert picture. $\mathrm{C}_{X} \mathrm{H}_{Y}{ }^{+}$refers to hydrocarbon fragments, $\mathrm{C}_{X} \mathrm{H}_{Y} \mathrm{O}^{+}$to organic fragments with one oxygen atom and $\mathrm{C}_{X} \mathrm{H}_{Y} \mathrm{OZ}_{Z}^{+}, \mathrm{Z}>1$ to organic fragments with more than one oxygen atom. m/z 36 was used as a surrogate for $\mathrm{rBC}$ and organics was divided into hydrocarbons and oxidized fractions based on the contributions of $m / z 57$ and 44 at different size fractions.
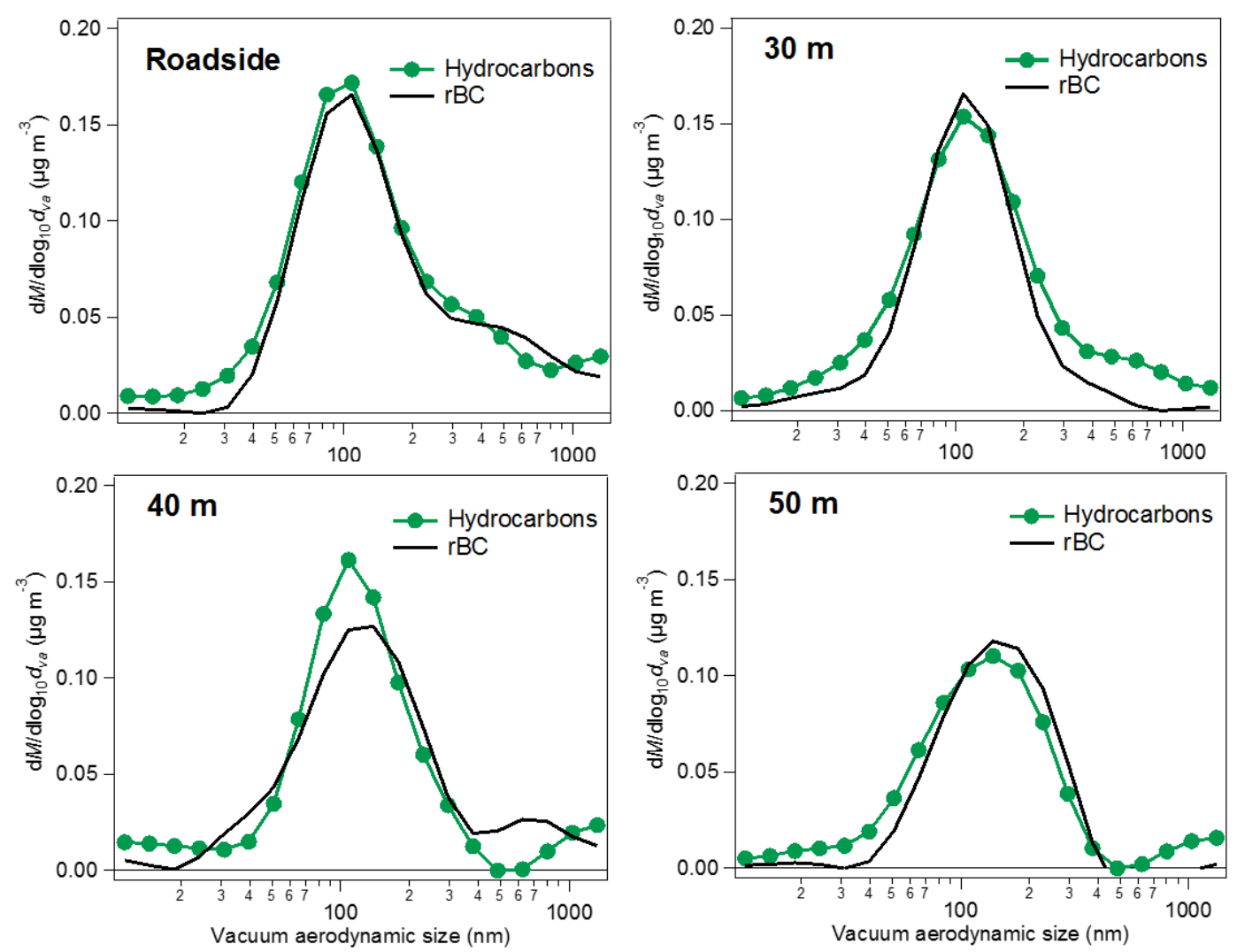

Figure S8. Particle size distributions for rBC and hydrocarbons at Herttoniemi on 26th of Oct 2012. Measurements at the roadside and 30, 40 and 50 meters from the road. $\mathrm{m} / \mathrm{z}, 57$ is used as a surrogate for hydrocarbon fragments and $\mathrm{m} / \mathrm{z}, 36$ for $\mathrm{rBC}$. 
a)

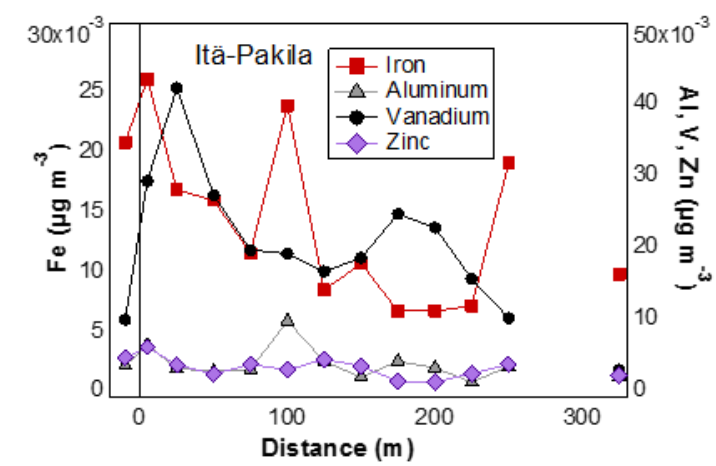

b)

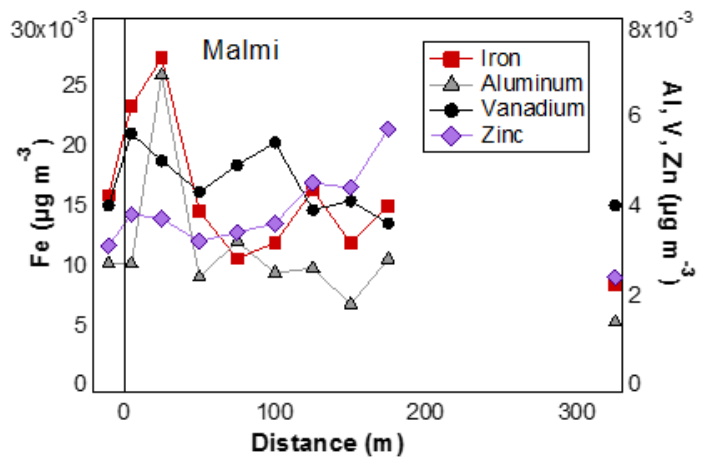

Figure S9. Concentration gradients for iron, aluminum, vanadium and zinc at Itä-Pakila and Malmi. Note difference in right side y-axes. Similar figures for Herttoniemi and Pitkäjärvi are presented in the paper.

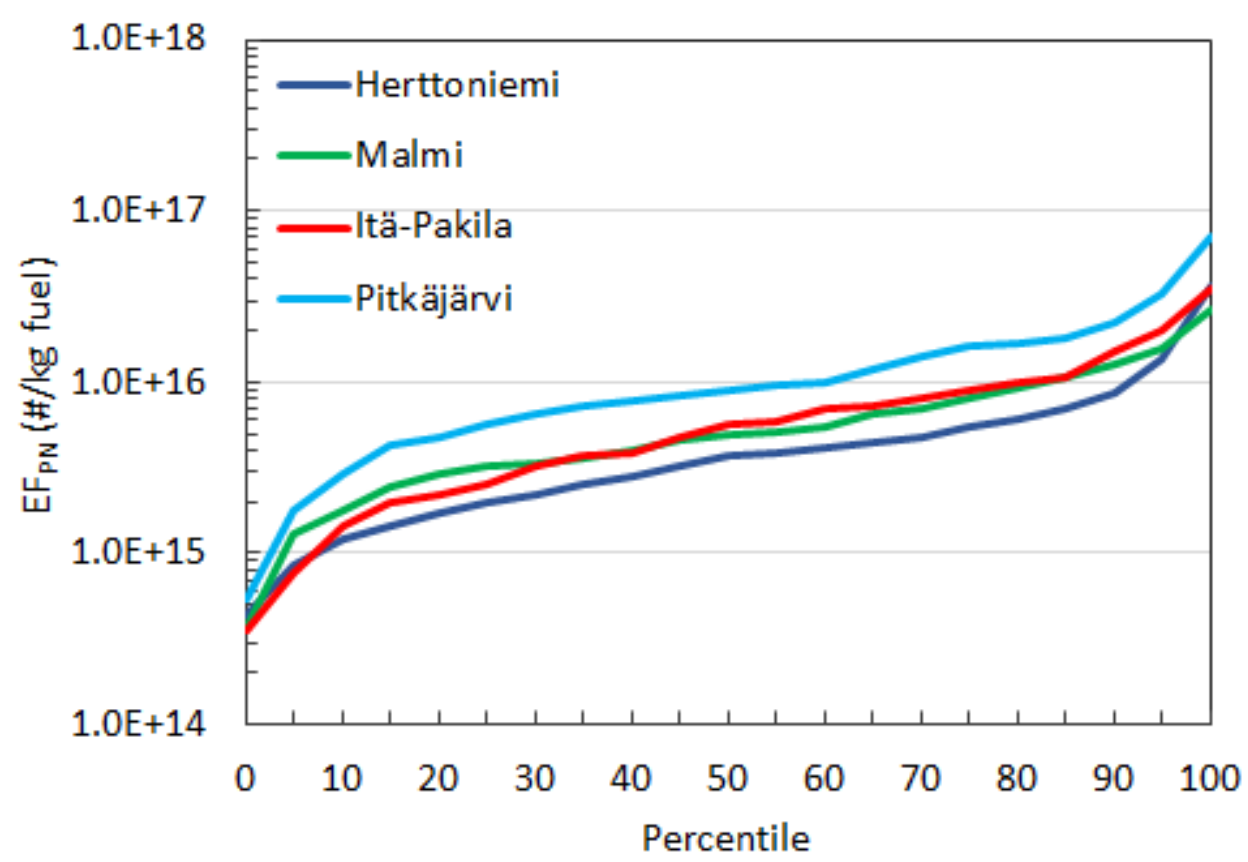

Figure S10. Distribution of emission factors EFPN for the four locations. The average fraction of HD vehicles for Herttoniemi, Malmi, Itä-Pakila and Pitkäjärvi was 2.9, 4.8, 2.8 and 8.7\%, respectively, and the total vehicle count 4010, 4630, 6060 and $3720 \mathrm{veh} /$ hour, respectively. 